\title{
Spinoza on the Passionate Dimension of Philosophical Reasoning
}

\begin{abstract}
An affect”, Spinoza tells us, "is only evil or harmful insofar as it prevents the mind from thinking." By implication, then, affects that do not prevent the mind from thinking are not harmful. But what affects are respectively harmful and harmless, and how is it that some prevent the mind from thinking while others do not? In the Theologico-Political Treatise Spinoza argues that a certain kind of passionate love plays a vital role in enabling ordinary, ignorant people to become capable of acquiring philosophical knowledge. Learning to think philosophically, I argue, is for Spinoza a theologicopolitical as well as an intellectual enterprise, and depends upon collective and as well as individual passions.
\end{abstract}

Spinoza writes at length about the epistemological deficiencies of the passions; but he also insists that some of them - notably a form of passionate love are conducive to philosophical reasoning. Without this kind of love, reasoning cannot get off the ground or be sustained by communities of ordinary people. So there is a sense in which love helps us to think: reason and passion work together, and the first depends on the second. Until recently, many commentators tended to overlook this feature of Spinoza's philosophy, preferring to emphasise the traditional dichotomy between the two categories that is undeniably present in his texts. However, led by the inspirational work of a sequence of French scholars, this orientation has lost its dominance. ${ }^{1}$ The close links between reason and passion, as Spinoza represents them, have come to be generally acknowledged, and the nature of their interdependence is recognized as one of his major themes.

There are, nevertheless, certain aspects of this relationship which have received comparatively little attention, and in this essay I explore one of them. In the Theologico-Political Treatise, Spinoza makes a form of passionate love definitive of a way of life that he calls true religion. As many commentators have pointed out, a truly religious way of life is meant to encourage people to

1 Leading figures here include Gilles Deleuze, Alexandre Matheron, Pierre Macherey and Etienne Balibar. In Anglophone philosophy, notable exponents of the same line of interpretation include Moira Gatens, Genevieve Lloyd and Amélie Rorty.

DOI 10.1515/9783110260922.71, (cc) BY-NC-ND (c) 2017 Susan James, published by De Gruyter. This work is licensed under the Creative Commons A ttribution-NonCommercial-NoDerivs 3.0 License. 
live together peacefully, but is organized around, and tolerant of, false beliefs. There is consequently a temptation to construe it as a panacea for the destructive passions of the ignorant masses. By encouraging the populace to live in a peaceful fashion, it seems, true religion generates conditions in which philosophers can pursue the truth. Nevertheless, religion does not itself pursue truth, and therefore has no part to play in the elite project of philosophising. I contend that this interpretation underestimates the depth of Spinoza's concern with the question of how ignorant, passionate people can become capable of acquiring philosophical knowledge. Addressing this problem, he maps the distinction between passion and reason onto a social nexus comprising theology, politics and philosophy, and provides an analysis of the social conditions and constellations of passion on which the growth of philosophical knowledge depends. Learning to think philosophically, as he presents it, is not merely an individual undertaking, but also depends on the passionate orientations of communities. It is a theologico-political as well as an intellectual enterprise, deeply sensitive to the various ways in which the affects can both enhance and impede our thinking and the ways of life in which they are embedded.

In one of the most thought-provoking propositions of the Ethics, Spinoza declares that "an affect is only evil or harmful insofar as it prevents the mind from thinking." 2 By implication, then, affects that do not prevent the mind from thinking are not harmful. But what affects are respectively harmful and harmless, and how is it that some prevent the mind from thinking while others do not? I shall argue that Spinoza answers these questions in two complementary ways, and that, although one of them is metaphysically subordinate to the other, both are essential to his account of the processes through which individuals enhance their capacity to think, progressively adjusting their passions to the demands and pleasures of philosophical reasoning. After drawing on the Ethics to sketch what is, perhaps, Spinoza's most obvious response to the questions I have posed, I shall explore a second line of reply that he articulates most clearly in the Theologico-Political Treatise.

2 "Affectus eatenus tantum malus seu noxius est, quatenus mens ab eo impeditur, quominus possit cogitare", Spinoza, Ethica in Gebhardt ed. 1924, vol. 2; translation in Spinoza, 1985, vol. 1; E5p9. (All translations are Curley's, and references to the Ethics follow the standard form.) 
How, then, do affects prevent the mind from thinking? In the Ethics, Spinoza distinguishes two types of affect and aligns them with two different kinds of thought, imagining and reasoning. When we imagine, we register the ways in which external things act on us. However, because the resulting thoughts or ideas are the fruit of random interactions that we do not determine for ourselves, and because the ways in which we interpret and act on them are governed by psychological laws of which we are largely ignorant, imagining is a passive form of thinking. ${ }^{3}$ Not that it renders us inert. On the contrary, we busily interpret the ideas that our senses, memories and fantasies deliver to us. The point is rather that, without the stimulus of external things, imagining would not occur, so that in imagining we are always directly or indirectly acted on.

The passivity of imagining is also reflected in its epistemological shortcomings. Rather than interpreting our perceptions, memories and so forth as a record of partial and arbitrarily-ordered interactions with external things, we normally regard them as reliable indications of what we and the world are like. ${ }^{4}$ As Spinoza puts it, we treat them like complete arguments when we should view them as "conclusions without premises", waiting to be examined and justified. 5 This disposition is damaging because the ideas that imagination works with are mutilated and confused, or as Spinoza usually puts it, inadequate, and consequently fall short of the truth. When our knowledge is limited to what we can learn by means of imagination, there are many types of error we persist in making, and many things we fail to understand.

Among the inadequate ideas that imagining delivers are our passions or passive affects - the varieties of laetitia and tristitia that register increases and decreases in our power as we interact with other things, together with the appetites and desires that such interactions generate. ${ }^{6}$ Like other inadequate ideas, passions do not present themselves to us in their true guise. Rather than

3 Our perceptions arise "I. from singular things that have been represented to us through the senses in a way that is mutilated, confused and without order for the intellect; for that reason I have been accustomed to call such perceptions knowledge from random experience; II. from signs, e.g. from the fact that, having heard or read certain words, we recollect things, and form certain ideas of them, which are like them, and through which we imagine them" (E2p40s2).

4 "The mind has only a confused and mutilated knowledge of itself, of its own body, and of external things, as long as it perceives things from the common order of nature, i.e. as long as it is determined externally, from fortuitous encounters with things, to regard this or that" (E2p29s).

5 "The ideas of the affections, insofar as they are related only to the human mind, are like conclusions without premises, i.e. [...] they are confused ideas" (E2p28).

6 E3p11. 
experiencing them as marks of our own fluctuating power, we tend to read them as appropriate response to the properties of external objects. (The tyrant is hateful and that is why I hate him; you are lovable and that is why I love you.) Moreover, by interpreting our affects in this way, we generate misleading ideas of ourselves and external things that often prompt us to behave selfdestructively.

The remedy for these deficiencies lies in a second kind of thinking, namely reasoning. When we reason, we form and connect what Spinoza describes as adequate ideas, which are not distorted, and possess a clarity and distinctness that reveals them to be true. ${ }^{7}$ Since an idea is adequate when we understand its causes, transforming our inadequate ideas into ideas fit for reasoning with is a matter of gaining a fuller grasp of the causal networks to which they belong. As one extends one's knowledge of the antecedent causes of an idea and the effects that follow from it, one's conception of it becomes less inadequate or confused. At the same time, one becomes progressively more able to think about it for oneself, in the light of one's knowledge of its causes and effects, and correspondingly less reliant on the inadequate, imaginative idea from which one began. To put the point another way, the more one thinks with adequate ideas, the less passive and more active one's thinking becomes and the more one's actions flow from one's active understanding. ${ }^{8}$

As we would by now expect, this transformation also has an affective dimension. By increasing our power of active thinking, understanding generates forms of joy that make the experience of reasoning a pleasurable one and are themselves classified as affects. But whereas our passive affects are caused by the way things act on us, these affects are an aspect of our own activity and are consequently described as active. Following a long tradition, the Ethics distinguishes the passive affects or passions that are integral to imagining from the active affects that are a feature of understanding.

In demonstrating his claim that the affects are only harmful insofar as they prevent the mind from thinking, Spinoza refers us back to two earlier propositions (E4p26 and p27) about what it is like to reason in the sense just described. According to Proposition 27, once we have learned to think with adequate ideas and experienced the joy they arouse, the mind "wants nothing other than understanding, nor does it judge anything to be useful to it except what really leads to understanding". Moreover, as our adequate knowledge increases, we come to recognize that "nothing is certainly good except what really leads us to understanding, and conversely, nothing is certainly evil except what can prevent us from understanding."

7 E2 Def. 4.

8 E3Def. 2; E4p3, p4. 
How, though, are we to pursue this conception of the good? The only way to extend one's understanding is to enlarge one's stock of adequate ideas; but in practice, our finitude makes it impossible for us to transform all our inadequate or passive ideas into adequate ones. Embodied and relatively powerless as we are, we cannot avoid being acted on by external things, and our minds are incapable of grasping all the causes of the multitude of inadequate ideas that this process generates. The development of our understanding is therefore inevitably both gradual and incomplete. As Spinoza recalls in a letter to Hugo Boxel, “when I learnt Euclid's Elements I first understood that the three angles of a triangle are equal to two right angles, and I clearly perceived this property of a triangle although I was ignorant of many others." By the time he wrote this sentence, we can presume, Spinoza was equipped with a fully adequate idea of a triangle; but some of his ideas still remained incomplete. "I do not say that I know God entirely, but only that I understand some of his attributes, though not all, nor even the greater part of them [...]". ${ }^{9}$ Reasoning or understanding is thus a matter of increasing as far as we can the proportion of adequate as opposed to inadequate ideas that our minds perceive, and thus increasing the extent to which our thinking is active rather than passive. ${ }^{10}$ Moreover, as we undergo this alteration we can expect to become increasingly strongly motivated to go on reasoning. The joy of active thinking generates a desire for more pleasure of the same kind so that, rejoicing in its own activity, the mind strives to increase its understanding.

By referring back to this earlier argument, Spinoza makes it clear that, when he says that the affects are only harmful insofar as they prevent us from thinking, the kind of thinking he has in mind is reasoning rather than imagining. So what sort of affects might impede reasoning? Obviously not the active ones. They play such an integral part in this form of thinking that it is impossible to reason without them. By elimination, then, Spinoza must be talking about the passive affects. If any affects are harmful to reasoning they must be passions, and in fact, the structure of oppositions we have been tracing makes it clear why this should be so. As we have seen, passions are inadequate ideas and are therefore not of the right type to reason with. At best, they will be neutral with respect to reasoning; but as Spinoza sees the matter they impede it. If we were not rendered passive by the way that external things act on us, our minds would not perceive any inadequate ideas and would be wholly active. If we were not led astray, as it were, by the passionate investments that imagining creates, our unobstructed, adequate thoughts would home in on the

9 Spinoza 1966, Letter 61.

10 E5p20s. 
causes and effects that constitute knowledge of our true good. As it is, however, passive affects hold us back. By distorting and mutilating our grasp of the world and ourselves they hinder our capacity to think, so that if we are to cultivate the activity proper to human minds we must do our best to transcend them. ${ }^{11}$

There is no doubt that Spinoza wants the readers of his Ethics to grasp this conclusion. It plays a vital part in the argument of the text, and paves the way for the account of liberation in which it culminates. However, although passive affects cannot by definition constitute reasoning, there remains the possibility that they may have a part to play in enhancing our ability to engage in this activity, and that some passions may be better suited to this role than others. When Spinoza says that nothing is useful to the mind "except what really leads to understanding”, he is reminding his audience that the reasoning mind focuses on its pursuit of adequate ideas, and emphasizing the difference between imagination and philosophical thought. But in driving these points home, he marginalizes a more positive conception of the relationship between passionate and rational thinking that he is elsewhere keen to defend. This latter conception does not challenge the argument we have so far traced, but it nevertheless contends that, without certain constellations of passion, we cannot cultivate the capacity to reason. Working within the realm of imagination, we can distinguish passive affects that inhibit thinking from passive affects that make it possible. We therefore do not need to condemn all passions as inimical to understanding.

Spinoza develops this aspect of his philosophical position most fully in the Theologico-Political Treatise, where he examines the process of increasing one's power to think, considering it not so much as an alteration that individuals undergo, but rather as a collective phenomenon. While it is true that a particular passion may increase or diminish an individual's capacity to reason, passive affects are usually more consequential when they are upheld by social practices and shared by groups of people. My hatred, for example, may harm me and those closest to me; but the common hatred of the members of a community is liable to have broader destructive effects, some of which may diminish its members' capacity to make themselves more active by extending their philosophical understanding. In the Treatise, moreover, Spinoza explains how different patterns of passive affect constitute different levels of empowerment, some of them more conducive than others to thinking. Institutionallysupported fear, he argues, impedes thought and, particularly in societies where superstition is rife, makes it extremely difficult to cultivate the general habit

11 E4p27. 
of reasoning; but institutionally-supported love is more productive. Love of this variety is undoubtedly passive, but it is not an obstacle to thinking. On the contrary, it is necessary for the practice of reasoning to take hold and become embedded in a collective way of life.

\section{II.}

Although the workings of the passions are lengthily dissected in both the Ethics and the Theologico-Political Treatise, the two discussions are set within different organizing frameworks, answering to the demands of imagining in one case and reasoning in the other. In the grand scheme of the Ethics, where Spinoza is largely concerned with the transition from imagining to reasoning (and ultimately to the further kind of thinking that he describes as intuition), he offers a single comprehensive account of the passive affects, defining them all as forms or combinations of laetitia, tristitia and cupiditas. Hatred, aversion, fear, despair and remorse are varieties of tristitia; love, devotion, hope, gladness and self-esteem are types of laetitia; and each of these passions comes in a host of forms, varying with its object and the constitution of the individual agent being acted on. One might expect the same classification to be employed in the Theologico-Political Treatise, written during an interlude in the long labour of composing the Ethics. But the Treatise serves a different purpose, and its treatment of the passive affects is adapted to its goal. While the Ethics locates imagination within the broader landscape of human thought, the Treatise aims to show how imaginative and therefore passionate people can avoid the deprivations latent in their own affective constitutions, and develop peaceful ways of life within which they can cultivate philosophical understanding. The work is therefore focused on the differences between better and worse forms of imaginative life, and on the distinct patterns of affect that characterize them.

Concentrating on this narrower domain, Spinoza organizes his argument (without comment) around love and fear. In doing so, he takes up a celebrated classical topos and enters a longstanding debate about whether it is better to rule by fear or by love. Posing a traditional question, he asks which of these two passions must dominate a political community of ordinary imaginative people if it is to be peaceful and secure. At the same time, however, he gives this standard query a less familiar twist by asking which affect a society should rely on to promote the growth of reasoning. Turning a familiar discussion in a new direction, he focuses on the relation between passion and knowledge. 
To many generations of writers, the answer to the traditional question had seemed obvious: societies flourish when their rulers strive to be loved. ${ }^{12}$ But by the time Spinoza was writing, this comfortable orthodoxy had been challenged by Machiavelli and Hobbes, two authors whose shadows loom large over the Treatise. Rejecting Cicero's faith in the benefits of benevolent government, Machiavelli had advised "that it is much safer to be feared than loved", and Hobbes had confirmed, in a memorable phrase, that "the passion to be reckoned upon is fear". ${ }^{13}$ Against this pair of influential dissenting voices, the Treatise reaffirms the efficacy of love, considered as a passive affect. Spinoza defends his restoration of classical orthodoxy on political grounds. (Inadequate and unreliable though passionate love may be, it is nevertheless essential to the cultivation of a politically harmonious way of life.) But he also has philosophical reasons for upholding it. One of the central aims of political society is to create conditions in which the freedom to philosophise can flourish, and love is a condition of achieving this end.

\section{III.}

As Spinoza acknowledges in both the Ethics and the Tractatus, a community whose members are already wise will be devoted to the project of extending their philosophical knowledge. Appealing to their adequate ideas and motivated by their active affects, they will strive to work out how it is optimal for them to live, and will develop ways of life geared to the harmonious pursuit of understanding. In practice, however, communities of this kind are extremely rare, if they exist at all. Ordinary societies are predominantly composed of individuals whose ideas are more inadequate than adequate, and whose thinking is more imaginative than rational. In deciding how to organize their collective affairs, these people have to rely on their imaginative resources, examining themselves in the light of their inadequate ideas and the passions that run through them, and doing their best to find ways of empowering themselves. Sometimes this process results in comparatively stable and effective ways of life, where there is room for philosophical understanding to grow. In other cases, however, the forms of social and political organisation that it generates are dysfunctional. There are, of course, many ways in which social institutions

12 The classic statement is Cicero, De Officiis (Cicero 1913). See I.16.41 on avoiding force and fraud, and especially II.7.23 on how being loved secures people and holds them to you, whereas being feared has the opposite effect.

13 Machiavelli 1988, 58 (ch. 17); Hobbes 1996, 99. 
can stand in the way of reasoning; but among these potential obstacles, Spinoza focuses on a way of life dominated by superstition, a condition in which the ability to think is choked by a peculiarly disabling form of fear. Superstition therefore provides a paradigm case of a harmful social practice in which a passion constitutes an impediment to thinking.

Like the pros and cons of fear and love, the political implications of superstition had been widely discussed by a long tradition of classical authors. On the one hand, superstition could pacify the people, thus making them easier to rule; on the other hand, it could make both rulers and subjects anxious and inconstant, thus destabilizing government. These possibilities are further explored in numerous sixteenth and seventeenth century works. In addition, however, early-modern writers take over a classical interpretation of the phenomenology of superstition (vividly described, for example, by Plutarch and subsequently rehearsed by philosophers, dramatists and medical authorities). ${ }^{14}$ Superstition, as these authors present it, is fundamentally a fear of the gods that typically manifests itself in various forms of anxiety, including insomnia, nightmares, fantasies and hallucinations. In an effort to assuage their fears, superstitious people habitually project them onto the world, imaginatively peopling the environment with witches or angels, good omens or bad. Needless to say, these fantastical devices are liable to let them down; but when they do so, the superstitious are not inclined to alter their outlook. Instead, they desperately repeat the same miserable cycle, shifting from one inadequate conception to another and prey to recurrent distress. As Plutarch (in Holland's translation) sums up the process,

Thus, unhappy and wretched superstition, by fearing overmuch and without reason, [...] never taketh heed how it submitteth itself to all miseries; and for want of knowledge how to avoid this passionate trouble [...] forgeth and deviseth for itself an expectation of inevitable evils, even unto death. ${ }^{15}$

Re-creating this image with his own philosophical materials, Spinoza traces the origin of superstition to the imaginative habit of forming anthropomorphic images of a God who serves human ends and satisfies human desires. ${ }^{16}$ By

14 Plutarch, 1603. On early early-modern reworkings of Plutarch's claims see James 2009, $80-98$.

15 Plutarch 1603, 262-3.

16 People first inferred that there was a ruler or rulers of nature who adapted things to human use. "And since they had never heard anything about the temperament of these rulers, they had to judge it from their own. Hence, they maintained that the Gods direct all things for the use of men in order to bind men to them and be held by them in the highest honour. So it has happened that each of them has thought up from one's own temperament different ways of worshipping God, so that God might love them above all the rest, and 
representing the deity as an extremely powerful being who, like an absolute monarch, can arbitrarily satisfy or thwart our desires, we make him an object of fear, thus subjecting ourselves to the very passion through which superstition "arises, is preserved and is encouraged". ${ }^{17}$ Since fear is a form of tristitia, it registers a diminution of power and is debilitating in itself; but the fact that superstitious anxiety is "an inconstant sadness that has arisen from the image of a doubtful thing" introduces two further forms of disempowerment that make it yet more destructive. ${ }^{18}$ First, because fear always alternates with hope, it is invariably accompanied by some degree of mental vacillation. As the Ethics puts it, "He who is suspended in hope [...] fears that the thing he imagines will happen, while he who fears hopes that the thing he imagines will not take place". ${ }^{19}$ However, vacillation and doubt also make us credulous. When we are not sure what to do or think, we are psychologically disposed to give more weight to our hopes than our fears, so that we "easily believe the things we hope for [...] and regard them more highly than is just." But acting on this basis cannot firmly dispel doubt, which simply resurfaces, driving us inconstantly from one opinion to another. Secondly, the doubt that accompanies fear makes us timid, and in extreme cases brings thinking to a halt by preventing us from resolving on a decision or course of action. In cases where fear significantly outweighs any accompanying hope, this is not a serious psychological threat. Hating the things we fear, we do all we can to oppose them. But in cases where we are divided between fear of a state of affairs and fear of what will happen if we resist it, we can find ourselves so torn between two alternating inclinations that, "willing what we do not will and not willing what we will”, we are unable to act. ${ }^{20}$ In this condition, Spinoza claims, we experience the passion of timidity (timor), itself a form of cowardice ${ }^{21}$ that he associates with superstition. (All the things men have worshipped in superstitious and illusory religions, he remarks, "have been nothing but apparitions, the delusions of a sad and timid mind."22) But when the alternating anxieties in ques-

direct the whole of nature according to the needs of their blind desire and insatiable greed. Thus, this prejudice was changed into superstition and struck deep roots in the mind" (E1 Appendix I).

17 Spinoza, Tractatus Theologico-Politicus in Gebhard ed. 1924, vol. 3, 5-6. (Henceforth I use the standard system of citation, e.g. TTP III/5.) All translations are from Edwin Curley's English edition of the Tractatus, forthcoming with Princeton University Press.

18 E3p18s2.

19 E3 Definition of the Affects, xiii exp.

20 E3p39.

21 E3 Definition of the Affects xlii.

22 "Eaque omnia, quae unquam vana religione coluerunt, nihil praeter phantasmata, animique tristis, et timidi fuisse deliria," TTP II/6. 
tion are very great, timidity turns into consternation (consternatio), a passion that arises from a double timidity and "keeps a man so suspended in considering it that he cannot think of other things by which he could avoid that evil". ${ }^{23}$ In this most acute form, superstitious fear makes us incapable of seeing what to do or how to remedy our own debilitating state.

Bringing these two afflictions together, Spinoza launches into a violent denunciation of the inconstancy and credulity of superstitious people, who vacillate wretchedly between hope and fear, have a mind ready to believe anything at all, are driven this way or that, and, especially when shaken by hope and fear, are unable to act. ${ }^{24}$

\begin{abstract}
If, while they are tossing in fear, they see something happen which reminds them of some past good or evil, they think it portends either a fortunate or an unfortunate outcome; so they call it a favourable or unfavourable omen, even though it may deceive them a hundred times. Again, if, with great wonder, they witness something strange, they believe it to be a portent, which indicates the anger of the Gods or of the supreme Divinity. Prey to superstition and contrary to religion, they consider it a sacrilege not to avert the disaster by sacrifices and prayers, and, as if nature were as insane as they are, interpret it in amazing ways. ${ }^{25}$
\end{abstract}

These habits of thought and action constitute an outlook that leans to madness and is deeply destructive. For one thing, it tends to spread. A general psychological disposition to try to affirm ourselves by getting others to share our ideas and ways of life works in this case to ensure that the superstitious try to get those around them to share their hopes and fears, along with the vacillation and inconstancy that accompanies them. ${ }^{26}$ They thus aim, as Spinoza puts it, "to make others as wretched as they are, so it is no wonder that they are generally burdensome and hateful to men". ${ }^{27}$ Furthermore, the attempt to satisfy the ever-changing needs of superstitious people generates a plethora of diverse practices, each with its own temporarily committed adherents, and thus sets the stage for conflict between them. Reflecting on his own experience, Spinoza bitterly condemns sectarian churchmen who, themselves the victims of superstitious fear, manipulate the anxieties of the populace in order to uphold their own status, and rails again sovereigns who employ the same device for political ends.

23 E3p52s; E3 Dftn of the Affects xlii; E3p39s.

24 TTP III $/ 5$.

25 TTP III $/ 5$.

26 E3p17; E3p31.

27 E4p63s. 
Alongside these familiar complaints, we also find a powerful strand of argument about the intellectual degradation that superstitious fear induces. The anxious vacillation around which it is constructed makes us impressionable and obsessive, and gives us an investment in a range of inadequate ideas. At the same time, it blocks our ability to reflect on our passionate condition or critically assess its effects and, by cutting us off from ordinary habits of truth-seeking, creates an obstacle to reasoning. Expressing the point in more general terms, the Ethics notes that people attached to superstitious beliefs and ways of life interpret their fear (which is really a debilitating form of tristitia) as a good, and, mistaking disempowerment for empowerment, appeal to superstition as a means of avoiding evil. ("If we just do what the omens prescribe, God will not be angry with us" or "This miraculous cure shows us that the pious will escape damnation".) But cultivating one form of disempowerment in order to avoid another is, Spinoza protests, antithetical to reasoning, which is by definition a means of increasing one's power. ${ }^{28}$ By contrast with understanding, superstition enacts the debilitating strategy of restraining people by fear, so that they flee evil rather than love virtue. ${ }^{29}$

Societies where superstition is used to uphold political power therefore engender a double form of servitude. On the one hand, superstitious practices propagated by absolutist governments can gain such a hold over the people that they will "fight for slavery as they would for their freedom". On the other hand, such practices "fill everyone's judgment with so many prejudices that they leave no room in the mind for sound reason, not even to be in doubt." 30 Superstition is not only a theologico-political pathology. It is also harmful because, by rendering us impotent in the face of our own anxieties, it prevents us from thinking.

\section{IV.}

Since seventeenth-century writers habitually characterize superstition as a form of false religion, it comes naturally to them to oppose it to true religion, and Spinoza is no exception. The political and intellectual deprivations of superstitious practices can be mitigated, he argues, by a truly religious way of life, hospitable both to political cohesion and philosophical inquiry. In delineating the principles and practice of true religion, Spinoza sketches a way of

28 E4p64, p65.

29 E4p63s; E4 App. xxxi.

30 TTP III/7. 
life organized around a constellation of passive affect, yet nevertheless conducive to understanding. Rather than preventing us from thinking, as superstitious fear does, true religion enhances our capacity to think and supports rather than hinders the project of learning to reason. While false religion undermines philosophical thinking, true religion sustains it.

On the basis of a long theological discussion occupying much of the Treatise, Spinoza identifies true religion with a form of love. The one and only tenet of a truly religious way of life, he claims, is that we should steadily love our neighbours by treating them charitably, honourably and justly. Since nothing beyond this pattern of behaviour is required, and since it depends on very few specific beliefs, there are hardly any doctrines to which religious people must subscribe. Moreover, the small number of tenets to which religious people must commit are open to individual interpretation, so that, as long as one's theological beliefs do not prevent one from living in a co-operative or loving fashion, they are acceptable. Drawing on the Bible, and indeed on other sources, individuals and groups are free to internalize any images and narratives that enable them to love their neighbours, whether by providing them with exemplars of virtue to imitate or by generating a desire to attain cooperative goals. However, since images and narratives are themselves signs, which are in turn one of the classes of ideas at work in imaginative thinking, true religion is also an aspect of the imagination. ${ }^{31}$ And since the affects integral to imagining are passive, it follows that the love of one's neighbour around which true religion is organized will be a passion, answering to Spinoza's definition of passionate love as "joy accompanied by the idea of an external cause". ${ }^{32}$ To love and be loved by one another, neighbours must act on one another in a way that generates some form of joy in each of them, specifically the kind of joy that we take in being treated justly, charitably and honourably.

Mutual love of this sort is, however, a two-sided process. In the first place, I shall only be able to experience my neighbours as lovable in circumstances where they are for the most part just and can on the whole be relied on to remain so. In this respect, Spinoza argues, a truly religious form of life is simultaneously a political one, in which our confidence in others is sustained by a framework of laws and punishments that uphold a common standard of co-operative behaviour. Such a way of life must be designed to generate and sustain neighbourly love; and when it succeeds it will also counter superstition. By creating conditions in which people are constrained to co-operate in ways that are on balance advantageous to them, truly religious communities

31 E2p29s.

32 E3 Dftn of the Affects vi. 
aim to put individuals in a position where they can see how to act for their own good. Protected from deep doubt and vacillation, they are not particularly vulnerable to the credulousness to which these states give rise; and seeing how to pursue their advantage, they are not exposed to the timidity or consternation that is liable to arise when people confront a choice of evils.

At the same time, a co-operative way of life requires individuals to be capable of loving their neighbours, an ability that may of course be blocked by their own affective constitutions. Someone who is eaten up by superstition, for example, may have such mutilated ideas of their interactions with their just and well-meaning neighbours that they experience the latter as a threat and come to hate them. Someone who is exceptionally proud may regard their neighbours with contempt and treat them accordingly. And so on. To avoid the disempowering relationships that such passions breed, individuals and groups must somehow use their imaginative resources to generate and sustain their capacity to love, and this, in Spinoza's view, is where religious images and narratives begin to be important. However inadequate they may be, imaginatively grounded ideas of God, such as those to be found in the Bible, can encourage and sustain our capacity to treat others justly; and where they have this effect, they fulfill a valuable function. So much so, in fact, that each truly religious individual is in Spinoza's view under something resembling an obligation to cultivate theological beliefs that will motivate them to live lovingly with others. Alongside its political element, true religion therefore has a theological dimension, and this is why it is properly described as theologicopolitical.

True religion is clearly designed to overcome the social conflicts that superstition promotes. In place of hatred and competition rooted in fear, it offers the possibility of security and confidence in one's fellows. But is there any reason to suppose that a truly religious way of life can enhance our capacity to think, and thus that love of one's neighbour is an aid to reasoning? At first glance, Spinoza's answer seems to be in the negative. The goal of a truly religious life, he emphasises, is not to pursue the truth, as philosophical reasoning does, but simply to create circumstances in which people are able to employ their imaginations to live together peacefully and harmoniously. Individuals may, for example, be motivated to co-operate by deeply inadequate anthropomorphic beliefs about God, envisaging him, for instance, as a father, a king or a judge. Moreover, given the differences between human beings, individuals and groups within and between communities will cleave to disparate and sometimes conflicting theological opinions. However, as long as such people manage to treat one another justly and honourably, there is no religious reason to work out which of their beliefs are correct. It seems, then, that 
although a religious way of life will be much more harmonious than a superstitious one, it remains indifferent to the truth-focused demands of philosophical thinking. The love of one's neighbour around which it is organized is accommodated to human beings in all their fallibility and ignorance, and does not impose psychological or epistemological demands that can be counted on to generate a more philosophical outlook. In the name of co-operation, truly religious communities will refrain from enquiring too closely into the means by which people form their religious beliefs or the degree of confusion that these beliefs exhibit. Instead, they will focus on the behaviour in which such beliefs are expressed ("Does this person treat their neighbours lovingly?"), and simply accept that individuals can lead pious lives on the basis of profoundly inadequate ideas. ${ }^{33}$

At first glance, then, true religion appears to be particularly devoid of the critical standards to which philosophers appeal, particularly uninterested in developing them, and particularly tolerant of falsehood. To learn to live religiously is to learn to accept loving individuals as they are, however crazy, setting aside differences in belief and outlook, and refusing to jeopardize the benefits of harmony by probing their convictions. In the Tractatus, where Spinoza sets out to show that the freedom to reason or philosophise is not incompatible with true religion, this argument plays a central role. However, while it highlights one aspect of a religious way of life, it leaves another in shadow. On closer inspection, we find that the capacity to think is enhanced in communities organized around love of one's neighbour, both because such societies afford the opportunity for thinking, and because they demand the cultivation of attitudes that are themselves conducive to philosophical reasoning.

The first of these two claims is straightforward. By allowing individuals and groups to arrive at their own religious beliefs and live in the light of them, truly religious communities create conditions in which people are free to examine their convictions and alter them as their understanding grows. Testing the truth or falsehood of one's beliefs by subjecting them to increasingly rigorous standards of confirmation becomes an option, and there is consequently space for people of a philosophical bent who want to press this process of clarification as far as they can, and make their ideas as adequate as possible. As long as philosophers continue to love their neighbours, true religion gives them latitude to transcend the limits of imaginative thinking and devote themselves to reasoning.

While this is not a trivial conclusion, it is nevertheless comparatively weak. To be sure, the imaginatively grounded pattern of affect around which true

33 TTP III/176. 
religion revolves does not prevent thinking, and to this extent is less harmful than superstitious ways of life dominated by fear. However, we still have no evidence that true religion actively encourages philosophical reasoning. It is equally hospitable to adequate and inadequate ideas, and is in fact upheld by inadequate ideas and passive affects that, judged by the light of reason, are profoundly mistaken and misdirected. ${ }^{34}$ So although truly religious communities give people the freedom to engage in philosophical reasoning if they can, they do not support their efforts and are not well-placed to do so.

There is, however, a further and more substantial way in which loving one's neighbour promotes attitudes integral to reasoning, this time by imposing a demand for what we might describe as intellectual respect. According to the Treatise, one of the vices that truly religious people must avoid is stubbornness - an adamant and unyielding adherence to beliefs and attitudes that one is sufficiently well placed to recognize as discredited. ${ }^{35}$ Spinoza's attack on this habit of mind is partly aimed at theologians who insist on upholding bankrupt interpretations of Scripture, but he is also making a general point: that among the actions to which true religion requires us to respond lovingly are people's expressions of their ideas. When groups or individuals voice opinions that differ from our own, religion calls on us to respond justly, honourably and charitably by giving their beliefs due consideration. As well as requiring us to put up with other people's ideas, neighbourly love demands that we treat one another as beings who are passionately invested in our ideas, and who strive to empower ourselves by communicating our thoughts to one another. Stubbornly refusing to consider the beliefs that people offer, and on which they ground their capacity to treat others justly and honourably, is consequently a failure of love. Willfully misinterpreting claims that we find unpersuasive is, for instance, a failure of charitas, liable to damage the freedom to reason that religious ways of life afford. Lazily dismissing an outlook is a failure of justice, embodying the kind of unfair treatment that true religion aims to overcome and jeopardizing the security that it aims to create. Deliberately ridiculing an opinion or trying to humiliate its advocates is a way of treating them dishonourably, thereby sowing the seeds of resentment and conflict.

These standards of intellectual respect are difficult for passionate people to achieve, and Spinoza himself sometimes fails to live up to them. However, like other aspects of a truly religious way of life, the capacity to respond lovingly to other people's beliefs and attitudes represents an ideal that may be more or less fully realised. Where a community is unable to create a political

34 E1 Appendix [I].

35 TTP III/176-7. 
structure capable of sustaining a recognizably just way of life, its rulers may find, as Machiavelli had pointed out, that it is safer to rule by fear. "The mob" (vulgus), Spinoza comments, "is terrifying if unafraid" and we therefore should not be surprised that even the prophets encouraged debilitating affects such as humility and repentance in order to control it. ${ }^{36}$ Nevertheless, this is a dangerous policy, because harmony born of fear "is without trust". ${ }^{37}$ It is consequently inimical to neighbourly love, and cannot avoid provoking the doubts on which superstitious anxiety feeds. As far as they are able, communities should therefore eschew fear as a tool for maintaining peace, and strive instead to develop loving ways of life.

A parallel argument applies to the communicative aspect of true religion. Where individuals or groups lack the imaginative resources to engage with outlooks that offend them, or are incapable of overcoming their own stubborn attachments to particular inadequate ideas, this dimension of neighbourly love will remain weak. But even where this is so, the evaluative structure of true religion will continue to hold out the possibility of a way of life where standards of justice and honour extend to the exchange of beliefs and opinions, and will impose a demand to cultivate stronger habits of critical self-reflection and fair assessment. Because learning to live co-operatively or lovingly is partly a matter of learning to think co-operatively or lovingly, communities that aspire to live in a truly religious fashion will strive to develop this capacity. Politically, they will aim to build institutions that promote co-operative thinking; and when individuals search for images and narratives to sustain and strengthen their neighbourly love, they will take this aspect of it into account. In doing so they will lay down and reinforce habits that protect them against the credulousness and doubt on which superstitious fear thrives, and by which thinking is degraded.

\section{V.}

Spinoza is adamant that the passive affect of neighbourly love falls short of the active joy and desire that reasoning generates, and that the inadequate ideas in which this form of love is embedded lack the clarity and distinctness on which philosophising trades. Excluded from reasoning, neighbourly love cannot be constitutive of philosophical thinking. However, as we have now

36 E4p54s.

37 E4 Appendix XV. 
seen, it is nevertheless constitutive of the conditions in which individuals and communities are able to think. Without a way of life organized around neighbourly love, ordinary imaginative people are vulnerable to corrosive and disempowering passions that inhibit, and at worst destroy, their ability to reason, exemplified in Spinoza's account by superstitious fear. Without neighbourly love, our attempts to recognize the distinction between inadequate and adequate ideas will remain stunted and fragile. Forms of social organization answering to Spinoza's description of true religion are therefore essential to the development of philosophical understanding, and as long as we remain passionate, will always be needed to sustain it. There is thus a robust sense in which the constellation of passive affects that make up neighbourly love does not prevent us from thinking and is not harmful. On the contrary, it helps us to think. ${ }^{38}$

\section{Bibliography}

Cicero, Marcus Tullius (1913), On Duties, trans. Walter Muller, Cambridge Mass.

Hobbes, Thomas (1996), Leviathan, Richard Tuck (ed.), Cambridge.

James, Susan (2009), "Shakespeare and the Politics of Superstition”, in: D. Armitage / C.

Condren / A. Fitzwaurice (eds.), Shakespeare and Early Modern Political Thought,

Cambridge, 80-98.

Machiavelli, Niccolò (1988), The Prince, Quentin Skinner / Russell Price (eds.), Cambridge. Plutarch (1603), "On Superstition" in The Philosophie commonly called, the Morals, trans. Philemon, Holland, London.

Spinoza, Benedict de (1924), Opera, 4 vols., Carl Gebhardt (ed.), Heidelberg. Ethica vol. 2, Epistolae vol. 4.

Spinoza, Benedict de (1985), Ethics in The Collected Works of Spinoza vol. 1, Edwin Curley (trans. and ed.), Princeton,

Spinoza, Benedict de (1966), The Correspondence of Spinoza, trans. Abraham Wolf, London.

38 An initial draft of this paper was presented at a conference attended by the contributors to this volume. I am extremely grateful to Sabrina Ebbersmeyer for inviting me to speak, and to the other members of the group for their learned and helpful comments on my talk. I am also indebted to Quentin Skinner, who generously read a later version and helped me to improve it. 